MEASURING REAL INVESTMENT:

TRENDS IN THE UNITED STATES

\title{
AND INTERNATIONAL COMPARISONS
}

Milka S. Kirova

Robert E. Lipsey

Working Paper 6404 
NBER WORKING PAPER SERIES

\title{
MEASURING REAL INVESTMENT: \\ TRENDS IN THE UNITED STATES \\ AND INTERNATIONAL COMPARISONS
}

\author{
Milka S. Kirova \\ Robert E. Lipsey
}

Working Paper 6404

http://www.nber.org/papers/w6404

\section{NATIONAL BUREAU OF ECONOMIC RESEARCH \\ 1050 Massachusetts Avenue \\ Cambridge, MA 02138 \\ February 1998}

The authors thank Bill Dewald for valuable discussions during the work on this article. We also thank Patricia Pollard and Peter Yoo for helpful comments, and Charles Horioka for providing the data on consumer durables in Japan. Eran Segev and Ewa Wojas provided research assistance. Any opinions expressed are those of the authors and not those of the National Bureau of Economic Research.

(C) 1998 by Milka S. Kirova and Robert E. Lipsey. All rights reserved. Short sections of text, not to exceed two paragraphs, may be quoted without explicit permission provided that full credit, including (C) notice, is given to the source.

Measuring Real Investment: Trends in the United 
States and International Comparisons

Milka S. Kirova and Robert E. Lipsey

NBER Working Paper No. 6404

February 1998

JEL Nos. C8, E21, E22

\begin{abstract}
The standard measures of nominal capital formation show the United States investing a proportion of GDP much lower than those of other developed countries throughout the last 25 years and falling further behind over time. In contrast, measures we have calculated in real terms across countries and over time indicate that US investment ratios have been rising over time and have been coming closer and closer to those of the other countries.

A broader measure of capital formation more consonant with economic concepts shows the United States to have been close to the other countries since 1970 and to have been investing an above average share of total output in the most recent period 1990-1994. Real capital formation per capita and per worker, even conventionally defined, has been consistently between 15 and 25 percent higher than in the other countries and broadly defined real capital formation per capita and per worker has been 30 to 60 percent higher.
\end{abstract}

Milka S. Kirova

Department of Economics

School of Business and Administration

Saint Louis University

3674 Lindell Boulevard

St. Louis, MO 63108
Robert E. Lipsey

National Bureau of Economic Research

50 East 42nd Street, 17th Floor

New York, NY 10017-5405

relqc@cunyvm.cuny.edu 


\title{
Measuring Real Investment: \\ Trends in the United States and International Comparisons
}

\author{
Milka S. Kirova \\ Robert E. Lipsey ${ }^{1}$
}

\section{Introduction}

In the early 1970 s, according to the standard OECD national accounts data, capital formation in the United States was about 19 per cent of its GDP, while in the other main developed countries capital formation was, on average, a quarter of their GDPs, an investment ratio a third higher. In 1990-1994, the ratios were closer, but the other developed countries were still investing at a rate about 23 per cent greater than that of the United States. That apparently low rate of U.S. capital formation, and its presumed effect on U.S. economic growth, were commented on, with alarm, in some of the Economic Reports of the President and in many other projections of U.S. economic prospects. During the first half of the period since 1970 the United States did grow more slowly than other developed countries in real income per capita, but in the second half, despite the higher investment rates in other countries, the United States retained its position of having a per capita income of more than a third above the OECD average and more than a half above the average for OECD-Europe. The apparent absence of large relative growth consequences of these low relative U.S. investment rates suggests that a careful look at the measures of investment rates may be in order.

In this paper we point out the importance of price trends and differences in price levels for real investment rates and also the consequences of accepting conventional measures of capital formation, the boundaries of which have more to do with the wide availability of data than with what economists define as "investment" or "capital formation."

\footnotetext{
${ }^{1}$ The authors thank Bill Dewald for valuable discussions during the work on this article. We also thank Patricia Pollard and Peter Yoo for helpful comments, and Charles Horioka for providing the data on consumer durables in Japan. Eran Segev and Ewa Wojas provided research assistance.
} 
What we refer to here as measures of investment "conventional" in scope, those imbedded in national income and product accounts, treat as investment, or capital formation, only physical capital investment, consisting of business and non-military government construction and purchases of plant and equipment, and purchases of owner-occupied housing. That has been the case despite a long tradition of theoretical arguments for broader concepts, going back at least over 100 years to Alfred Marshall's Principles of Economics (1890), and including the development of human capital theory in the work of Friedman and Kuznets (1945), Becker (1964), Mincer (1974), Schultz (1961), and many others. The use of the conventional measures also ignores the alternative measures, including various elements of human and other intangible capital that have been produced for the United States by Kendrick (1976), Eisner (1989), and others. The most radical of these measures, by Jorgenson and Fraumeni (1989), suggests that the conventionally defined capital formation we give such attention to is almost trivial, accounting for only about 5 per cent of a broadly conceived measure.

We have concentrated on the comparison of ratios of capital formation to GDP rather than saving to GDP. If a country is receiving large inflows of capital from abroad or investing heavily in foreign countries, the two ratios could be quite different. Since the U.S., for example, has been running a substantial current account deficit in the balance of payments for many years, the saving ratio must be lower than the capital formation ratio, although it may not be lower relative to the average of other countries. The conceptual changes in the scope of capital formation used in this paper imply corresponding changes in measures of saving, because items conventionally classified as consumption are removed from that category. These include household and government current expenditures on education, government and business expenditures on R\&D, household expenditures on durable equipment, and government expenditures on military capital formation. Their removal from the consumption category would raise levels of saving.

The conventional comparisons of capital formation across countries are not only narrow in scope, but also ignore the implications of large differences in prices of capital goods, and in prices of capital goods relative to prices of goods in general, from one country to another. The effect of these differences is that a given nominal amount of capital formation in one country can yield considerably more real physical 
or human capital and more relative to real GDP than the same nominal amount in another country. In a similar way, comparisons over time of nominal investment ratios in individual countries ignore trends in relative prices of capital goods and output in general. A stable ratio of nominal capital formation to nominal output could represent a rising or falling trend in the contribution of capital formation to growth. It would be a rising trend if prices of capital goods were falling relative to prices of goods in general; it would be a falling trend if prices of capital goods were rising relatively.

Over the last decade there has been a revival of interest in research that focuses on understanding and explaining the sources of long-term economic growth. Some of the new approaches that seek to overcome the limitations of the traditional neoclassical growth model emphasize redefining capital as a broader measure that includes not only physical capital, but also other types of reproducible intangible capital, such as human capital and the state of knowledge. Empirical studies employing the broader concepts of capital accumulation to explain economic growth have been carried out by Barro (1991), Mankiw, Romer, and Weil (1992), and Nonneman and Vannhoudt (1996). They indicate that adding nonconventional elements to the measures of capital formation substantially improves the ability to explain rates of growth. These studies necessarily rely on crude proxies for most of the additions to conventional capital formation because they cover large numbers of countries. We hope we can do better on the measurement side for the developed countries studied here, but leave the possible connection with economic growth for later research. ${ }^{2}$

\section{The Conventional Comparison of Capital Formation}

The conventional story of U.S. investment in comparison with that of other developed countries is shown in Table 1.

\footnotetext{
${ }^{2}$ For an earlier study of roughly the first half of the period, covering fewer countries, see Lipsey and Kravis (1987), Chapter 2.
} 
Table 1

Nominal Gross Fixed Capital Formation as a Per Cent of Nominal GDP:

U.S. Relative to 12 Other OECD Countries ${ }^{3}$

Per Cent

$\begin{array}{ll}1970-1974 & 75.3 \\ 1975-1979 & 81.6 \\ 1980-1984 & 90.6 \\ 1985-1990 & 87.6 \\ 1991-1994 & 83.2\end{array}$

Source: Appendix B, Table B-1

The United States has persistently invested less of its GDP, in nominal terms, than the average of the other 12 OECD countries we examine here. From the early 1970s to the early 1980s the United States drew closer to the other countries but the ratio then declined relative to the others through the early $1990 \mathrm{~s}$.

The changes in the relative investment ratios were not primarily the result of any major shift toward higher investment in the United States. Average nominal investment ratios in the other 12 countries fell from 25 per cent in 1970-1974 to 20 per cent in 1990-1994, a decline of 20 per cent while the U.S. ratio stayed around 19 per cent until it dropped in the latest period to about 16 per cent. At the end of the period, the United States ranked eighth among the 13 countries covered here, below Belgium, Canada, France, Germany, Japan, Netherlands, and Norway. Thus, in terms of the conventional measure of "investment effort" or the sacrifice of current consumption for future growth, the United States appears to have remained somewhat of a spendthrift relative to other developed countries, more of a grasshopper than an ant.

\section{The Price of Capital Goods and Real Capital Formation}

The ratio of capital formation, however defined, to total output reflects both the country's willingness to sacrifice present consumption for growth and future consumption and the willingness of other countries to invest their capital there. That ratio does not indicate how much capital is being

\footnotetext{
${ }^{3}$ Belgium, Canada, Denmark, Finland, France, Germany, Italy, Japan, Netherlands, Norway, Sweden, and the U.K.. The list was determined by the availability of data.
} 
acquired or how much relative to output, because it does not take account of the price of capital goods, relative to the price of other goods and services. That relative price varies over time in any one country, and it varies considerably across countries. In a single country over time, if the price of capital goods is falling relative to other prices, a constant nominal ratio of capital formation to total output would mean a rising real capital formation ratio, possibly producing accelerating growth or offsetting decreasing returns to capital. Similarly, if country A and country B have the same total output and the same ratio of capital formation to total output, but country A has a price of capital goods relative to total output half as high as country B, country A should enjoy twice as great an impact from its capital formation. Whatever influence capital formation has on future growth should be correspondingly greater.

We estimate real capital formation and real capital formation ratios across countries here by making use of estimates of purchasing power parities for capital goods and for output in general from the United Nations' International Comparison Program (ICP) and derivatives from that program calculated for intervening years by the OECD and by Summers and Heston (1991). ${ }^{4}$ The purchasing power parities, in combination with market exchange rates, give us prices for capital goods and GDP as a whole.

Trends in real capital formation ratios from 1970 to 1994 were affected by changes over time in the relation of capital formation prices to prices in general. In the United States, for example, the price of capital formation rose about 7 per cent relative to that of GDP from 1970 through 1981 . Then it began to fall in relative terms, until by 1994 it had reached 20 per cent below the 1970 level (Figure 1). This trend in relative prices implies that after 1981 the U.S. capital formation ratio in constant 1970 prices rose relative to that in current prices. The real capital formation ratios for the U.S. calculated using 1970 prices are compared with the ones in current prices in Table 2.

\footnotetext{
${ }^{4}$ The program and its methods are described, for the earlier years, in Kravis, Kenessey, Heston, and Summers (1975) and Kravis, Heston and Summers (1978) and (1982). For a description of later developments see Kravis and Lipsey (1991).
} 
Table 2

Ratios of Conventional Capital Formation to GDP for the US
$\begin{array}{ccc} & \text { Current prices } & 1970 \text { prices } \\ 1970-1974 & 18.8 & 18.6 \\ 1975-1979 & 19.3 & 18.5 \\ 1980-1984 & 19.3 & 18.4 \\ 1985-1989 & 18.6 & 19.1 \\ 1990-1994 & 16.3 & 19.4 \\ \end{array}$
Source: Appendix B, Table B-1

The most striking difference between trends of capital formation ratios in nominal terms and trends in real terms is that the large decline in the nominal ratios between 1980-84 and 1985-89 and the even larger one between 1985-89 and 1990-94 disappear completely when capital formation is measured in constant prices. The U.S. capital formation ratio in real terms shows increases in both periods, adding up to about a five per cent increase in the last decade. 
Figure 1: Price of Capital Formation to Price of GDP Ratio

(US 1970=1)
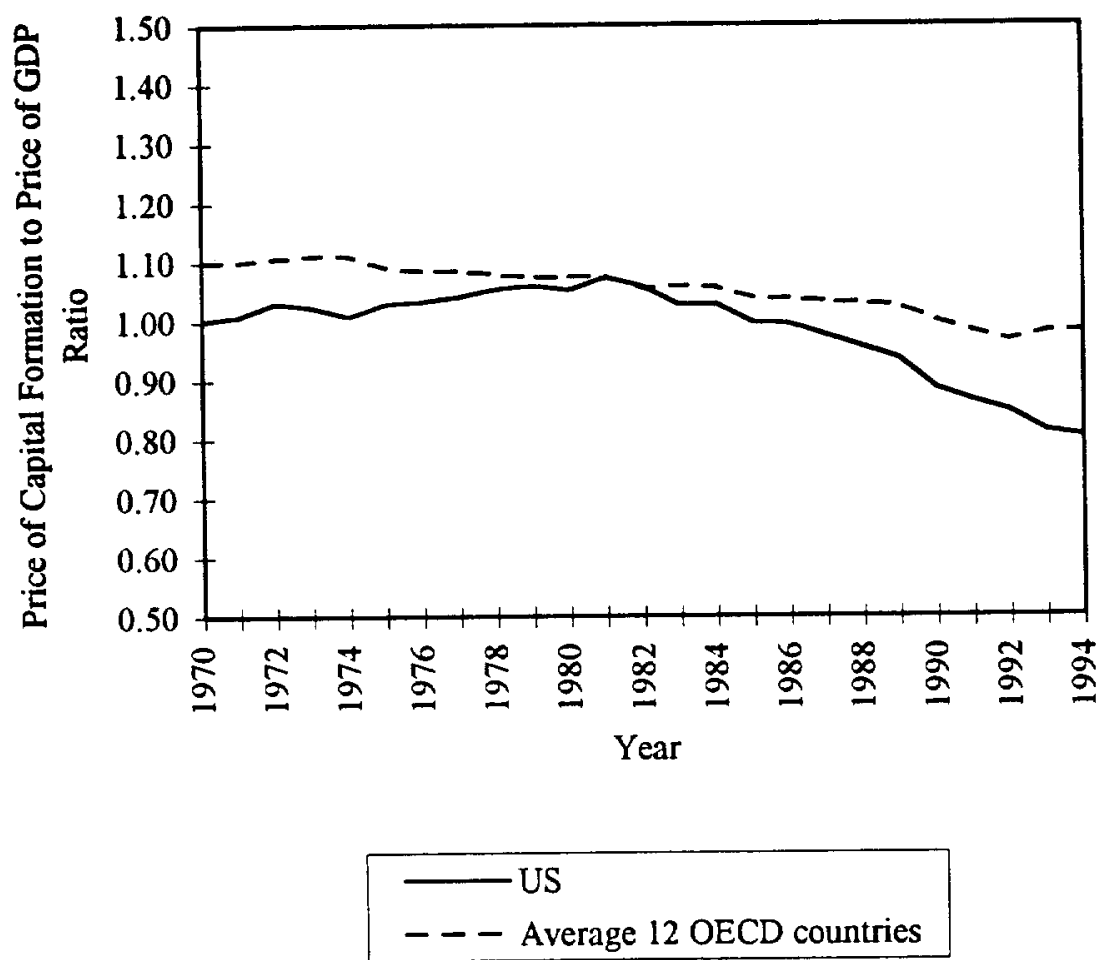

We can compare capital formation ratios in the United States with capital formation ratios in other countries by using price level measures based on world prices, so that if two countries had the same level of real GDP, measured at world prices, and the same real ratios of capital formation to GDP, they would have the same real capital formation, that is, the same amounts of additions to their capital stocks in physical terms. Investment goods, conventionally defined, were generally cheaper in the United States than in other countries, as might be expected from the fact that the United States has had a comparative advantage in trade in capital equipment. Therefore, the United States gets more real capital formation per unit of consumption sacrificed than do other developed countries.

Conventional capital goods were cheaper in the U.S. than in the other 12 OECD countries in every period, but the differential has varied over time. The price of capital goods in the other 12 countries has been falling relative to that of GDP throughout the entire period 1970-1994, but not as much as in the U.S. (Figure 1). The differential between relative prices in the U.S. and relative prices in the other 12 
countries has been rising steadily since the beginning of the $1980 \mathrm{~s}$. The price of capital goods relative to that for all goods and services has fallen in the U.S. by more than 10 per cent as compared with relative prices in the other countries, mainly because of the rapid fall in relative prices in the U.S. after 1981.

We calculate real capital formation ratios comparable over time and across countries for the other 12 OECD countries by using constant world prices for capital formation and GDP. The real capital formation ratios for the 12 OECD countries implied by the use of PPPs and constant world prices are compared with the ones in current own-country prices in Table 3.

Table 3

Ratios of Conventional Capital Formation to GDP for 12 OECD countries other than the US

Current PPPs and
national $\quad 1970$

prices world prices

$\begin{array}{lll}1970-1974 & 25.0 & 22.7 \\ 1975-1979 & 23.8 & 22.0 \\ 1980-1984 & 21.3 & 20.1 \\ 1985-1989 & 21.3 & 20.6 \\ 1990-1994 & 19.7 & 20.1\end{array}$

Source: Appendix B, Table B-1

The real capital formation ratios in the other 12 countries have been lower than the nominal capital formation ratios in every period, except for 1990-1994. The decline in real capital formation ratios between 1970-74 and 1975-79 and between 1985-89 and 1990-94 has been much less than the nominal ratios suggest. Since the beginning of the 1980 s we do not see much change in the average real capital formation ratios for these countries.

The relation of the United States to the other 12 countries in terms of the real shares of conventional capital formation in GDP, measured using constant world prices, is quite different from that in nominal terms, measured using current own-country prices, as can be seen in Table 4. 
Table 4

Real Ratios (Adjusted for Purchasing Power Parities) of Conventional
Capital Formation to GDP: US Relative to 12 Other Developed Countries
Per Cent

1970-1974 82.0

1975-1979 84.3

1980-1984 91.9

1985-1989 92.9

1990-1994 97.5

Source: Appendix B, Table B-1

These figures tell a very different story from that of Table 1. U.S. investment ratios in real terms have been closer to those of the other countries, have been moving toward the average, and, by 1990-1994, were only three per cent below the average of the 12 other countries. The U.S. ratios were even above the average of the others in 1993 and 1994. In real terms, in 1994 the United States ranked third among the 13 countries in the ratio of conventional capital formation to output, below only Canada and Japan.

\section{The Measure of Capital Formation}

\subsection{Gross vs. Net Capital Formation}

The capital stock that enters production functions is the net capital stock and additions to the stock are measured by net, rather than gross capital formation. Despite the theoretical advantages of the use of net capital formation, much empirical research, especially that involving comparisons among many countries, has concentrated on gross capital formation, a tradition that goes back to Kuznets (1937). We follow that tradition, confining our attention to gross capital formation. There are several reasons for that choice. One is skepticism regarding available measures of capital consumption, and particularly their comparability among countries (Blades and Sturm, 1982). For example, Hayashi (1986) pointed out that Japanese depreciation had been calculated on the basis of historical cost and that the adjustment to a replacement cost basis amounted to as much as 30 per cent of reported private saving in some years. Another reason for the use of gross measures is the belief that the introduction of new capital equipment 
brings new technology into the production process, whether or not the new equipment is nominally a replacement for old equipment embodying past technology. If technology, rather than the "volume", in some sense, of capital equipment, is what drives economic growth, it is the gross rather than the net capital formation that is relevant for explaining growth. A country in which gross capital formation is equal to calculated depreciation, and therefore resulted in no net capital formation, would nevertheless reap economic growth from the substitution of new technology for old technology.

Since we are not studying the relation of capital formation to growth here, we cannot draw a conclusion as to which concept of capital formation is more relevant empirically. We can only mention the caution that a shift in the composition of capital formation that changes the average length of life of capital goods (e.g., from buildings to computers) would change the relation of net to gross capital formation.

\subsection{Broadening the Definition of Capital Formation}

The conventional measures of capital formation have remained essentially unchanged since most countries began publishing national accounts. ${ }^{5}$ Many expenditures that fit the economic definition of capital expenditures, in that they yield income over a period beyond the current one, are excluded, despite the theoretical reasons for including them. One reason for limiting the measurement is the lack of data on some types of investment, especially for international comparisons. Most of the empirical research on broadening the definition of capital formation has been done only for the United States or, sometimes for a few other countries. That fact limits our country coverage and, in some cases, forces us to depend on rough approximations to the measures we would like to use, even for the 13 countries we have covered.

Most of the empirical studies of economic growth that have included non-conventional elements of capital formation have concentrated on education, as an aspect of human capital investment, and research and development, as an aspect of intangible, non-human capital investment. We have included

\footnotetext{
${ }^{5}$ An exception is the recent adoption in the U.S. National Income and Product Accounts of the standard definition of investment according to the UN System of National Accounts to include government capital formation, long after that definition had been applied to the accounts of the U.S. and other countries by the OECD. The change represented a return also to the scope of investment in Kuznets' earlier calculations, for example in Kuznets (1937).
} 
both of these here, as best we could, and added two others, capital formation in the form of consumer durables, of which motor vehicles are the largest part, and military capital formation, which meets the criterion of usefulness beyond the current period. Ideally, if the determinants of economic growth are the use to be made of these data, the choice among investment concepts should be made empirically.

\section{A. Consumer Durables}

The treatment of consumer durables in the conventional national accounts divides expenditures not by the nature of the goods acquired or by the nature of their use, but by the institutional characteristics of the buyers, business or household. The arbitrary nature of this division is avoided for housing by the treatment of house purchases as capital formation and the inclusion of imputed income and output from home ownership. We extend the same treatment to consumer durables, a procedure for which we have the strong endorsement of Alfred Marshall over 100 years ago. ${ }^{6}$ These goods produce services over a long period of time and the services are, in many cases, very similar to those yielded by the durables bought by business. Cars, the largest item in consumer durables, give transportation service whether they are owned by businesses or by households. Some of those owned by businesses are leased to households for their own use. Refrigerators, freezers, or laundry machines often provide services to households even if they are owned by businesses. In fact, the distinction between consumer and producer durables in the national accounts rests on ownership rather than on their function. The effort to allocate sales of some durables, especially motor vehicles, between households and businesses has been a difficult and frustrating chore for the BEA for many years.

To treat purchases of consumer durables as capital formation in the same way as purchases of owner-occupied housing, it is necessary to make two adjustments. One is to add to conventional gross fixed capital formation household expenditures on consumer durables (treated as consumption in both the

\footnotetext{
${ }^{6}$ Alfred Marshall (1890) wrote, in discussing a narrow concept of investment, “... it compels us to regard as capital the yachts, but not the carriage, belonging to a yacht builder. If therefore he had been hiring a carriage by the year, and instead of continuing to do so, sold a yacht to a carriage builder who had been hiring it, and bought a carriage for his own use, the result would be diminished by a yacht and a carriage. ... though nothing had been destroyed, and though there remained the same products of saving ... productive of as great benefits to the individuals concerned and to the community as before...".
} 
SNA and the U.S. national income accounts). The second is to add to consumption and output a measure of the current services yielded by consumer durables.

The comparison between the shares in GDP of nominal capital formation in consumer durables in the U.S. and in the other 12 countries is described in Table 6.

Table 6

Share in Nominal GDP ${ }^{7}$ of Nominal Capital Formation in Consumer Durables Per cent

U.S. $\quad 12$ Other Countries

$\begin{array}{ccc}1970-1974 & 6.3 & 5.6 \\ 1975-1979 & 6.4 & 6.0 \\ 1980-1984 & 5.5 & 5.4 \\ 1985-1989 & 6.5 & 5.9 \\ 1990-1994 & 6.0 & 5.4\end{array}$

Source: Appendix B, Table B-2

The share in GDP of investment in consumer durables has been higher in the U.S. than in the other 12 countries in every period. The U.S. has invested on average $6.1 \%$ of its total income in consumer durables, while the other $12 \mathrm{OECD}$ countries have invested on average $5.6 \%$. The country with a particularly low investment in consumer durables was Japan with an average of $3.6 \%$ of total income invested in durables, while Belgium was the leader (7.9\%), followed by Canada (7.6\%) and the United States (6.1\%). During the 1970 s the real stock of consumer durables per capita in the United States was about four times as large as in Japan. Within consumer durables, the main differences between the United States and other countries were in spending for motor vehicles. Over the period 1970-94 consumers in the United States allocated on average half of all durables goods expenditures for purchases of personal transport equipment. Similar patterns of allocation of consumer durables expenditures are observed in the United Kingdom, where $48 \%$ of all durables spending was on motor vehicles, Finland (46\%), and Denmark (45\%). The share of motor vehicles spending in all durables goods expenditures was much lower in Belgium (29\%), Japan (32\% in 1975), Canada (35\%) and Italy (35\%). 


\section{B. Education}

Many forms of human capital formation would, ideally, be included in a broad measure.

However, for practical reasons of data availability, empirical measures have been confined to education in studies dealing with comparisons among countries. Some studies of economic growth have used data on enrollments at various schooling levels or measures of educational attainment, derived from Census data or estimated from past enrollment data. Others use current expenditures on education, as we do (capital expenditures in the form of buildings and equipment are already included).

Expenditures on education, whether by governments, employers, or households, are expected to yield returns over long periods of time. Some, perhaps most, of the returns are in the form of higher earnings in the labor market. We do not confine the investment concept to those entering the labor force any more than conventional capital expenditures are so confined; there is plenty of evidence that returns to education are not only long-lasting but are important in the non-market economy as well. Many of these have been studied empirically, including effects on the educational attainment of children and their educational performance. Education also affects individual behavior with respect to smoking and other health-related decisions. It should be added, however, that some have argued that both these health decisions and education decisions are reflections of differences among individuals in time horizons and time preferences.

There are two large elements of human capital accumulation that we are missing. One is on-thejob training, particularly if it is "general" training, in Becker's sense (Becker, 1964), that is paid for by the worker in the form of temporarily low wages. The other is the earnings foregone by students in the course of their education. In both cases, estimates have been made for individual countries but not, by the same methods, for any substantial group of countries. It is clear from individual country estimates that the missing portions are large compared with those we include. ${ }^{8}$ The omission of foregone earnings is

\footnotetext{
${ }^{7}$ Here GDP is adjusted to include the estimated value of services yielded by consumer durables.

${ }^{8}$ Mincer (1989) presents estimates of the annual costs of training in the United States for 1976 and 1982 which suggest that job training costs in the United States amount to $80-90 \%$ of public and private expenditures on education. Kendrick (1976) estimates that for the United States in 1969 total gross
} 
probably more important in the United States than in the other countries because the support given to college and graduate students in the U.S. is smaller than in the other countries and because youth unemployment is lower in the U.S..

Education is what is described in the International Comparison Program (ICP) as a "comparisonresistant service." Deflators (purchasing power parities) are provided for use in calculating real consumption, but it is difficult to compare either the quantity of educational output, that is, learning, or even the quantities of inputs, since the qualifications of teachers at given levels of school may differ greatly among countries. International test comparisons may provide some clue to quality of schooling but these so far cover a very narrow slice of what schools are supposed to be teaching.

The comparison between the shares in GDP of nominal expenditures on education in the U.S. and in the other 12 countries is described in Table 7.

Table 7

Share in Nominal GDP of Nominal Expenditures on Education

Per cent
U.S.
12 Other Countries

$1970-1974$

7.1

5.1

1975-1979

6.7

5.6

1980-1984

6.2

5.6

1985-1989

6.0

5.4

1990-1994

6.6

5.6

Source: Appendix B, Table B-3

Over the period that we cover the U.S. has spent on average $6.5 \%$ of its total income on education, while the other 12 countries have spent on average $5.5 \%$. As was the case for consumer durables, the gap between the United States and the other countries was largest in 1970-1974 and smallest during the 1980s. Canada was the leader in educational spending with an average of $6.8 \%$ of GDP invested in education, followed by the United States (6.5\%) and Denmark (6.3\%). Japan and Germany were the

investment on education and training was $\$ 192.3 \mathrm{bln}$, of which $\$ 92.3$ bln were earnings foregone by students. 
outliers in this respect, spending much less on education than other countries did ( $4.1 \%$ and $4.4 \%$, respectively).

\section{Research and Development}

$\mathrm{R} \& \mathrm{D}$ is an activity that is probably more forward-looking than most investment in equipment. While the private depreciation rate may be high, as imitators rush to catch up with innovators, the social rate of depreciation may be low, because the usefulness of new knowledge endures. Whatever the speed of imitation, high rates of R\&D seem to promote rapid economic growth.

Incorporating $\mathrm{R} \& \mathrm{D}$ expenditures into the measures of capital formation involves, in some cases, an addition to the measure of total output as well. The shift of government and private non-profit R\&D does not require any adjustment to GNP or GDP, since they are treated in the SNA and the U.S. NIPA as government and household sector consumption, and therefore as final product. However, business enterprise expenditures on R\&D are treated in these accounts as costs of current production. The shift to treatment of these as capital formation and their removal from current expenditures on inputs raises the level of business enterprise income and gross output.

The comparison between the shares in GDP of nominal expenditures on research and development in the U.S. and in the other 12 countries is described in Table 8.

Table 8

Share in Nominal GDP ${ }^{9}$ of Nominal Expenditures on R\&D

Per cent
U.S.
12 Other Countries

1970-1974 2.4

1.5

1975-1979

2.2

1.5

1980-1984

2.5

1.7

1985-1989

2.8

2.0

1990-1994

2.7

2.1

Source: Appendix B, Table B-4 
The U.S. has consistently invested more of its total income in research and development activities than the average of the other 12 countries. Over the period 1970-1994, R\&D expenditures in the U.S. accounted for $2.5 \%$ of GDP on average, compared to $1.8 \%$ in the other 12 countries. The trend seems to be for the other countries to catch up somewhat to the United States. In this item Germany and Japan have been relatively high among the other countries and very close to the United States with an average of $2.4 \%$ of GDP invested in R\&D, as have been Sweden and the United Kingdom ( $2.3 \%$ and $2.2 \%$, respectively), while Canada, close to the United States in many respects, has been a relatively small investor, with an average of $1.3 \%$ of GDP invested in R\&D.

\section{Military Capital Formation}

It is conventional, and part of both the UN's System of National Accounts and the U.S. National Income and Product Accounts, to treat expenditures on construction and equipment for defense as current government consumption rather than capital formation. Yet, whatever their other faults and virtues, and whatever their effects or lack of contribution to the growth of non-military output, these expenditures are intended to yield output over a long period of time. If we are interested in the extent to which a country sacrifices present consumption for future gains, these expenditures are as relevant as those for civilian capital formation. A more radical view would argue that almost all military expenditures are a form of investment, since they provide not only current protection but protection extending into the future. If high levels of U.S. spending on military personnel, ammunition, fuel, and other non-equipment items forced an end to the Cold War, they could be thought of as having very long-lasting impacts on U.S. (and perhaps worldwide) welfare.

The comparison between military capital formation ratios of the U.S. and the other 12 countries is described in Table 9.

\footnotetext{
${ }^{9}$ Here GDP is adjusted to include business enterprise expenditures on R\&D.
} 
Table 9

Share in Nominal GDP of Nominal Military Capital Formation

Per cent

U.S. $\quad 12$ Other Countries

$\begin{array}{lll}1970-1974 & 1.5 & 0.5 \\ 1975-1979 & 1.0 & 0.5 \\ 1980-1984 & 1.4 & 0.6 \\ 1985-1989 & 1.7 & 0.6 \\ 1990-1994 & 1.3 & 0.5\end{array}$

Source: Appendix B, Table B-5

It is no surprise that in this relatively small item, spending by the United States has been much larger than the average relative to GDP, ranging between two and three times as great. Again, Japan's spending has been at a particularly low level ( $0.2 \%$ of GDP on average), partly because of the restrictions imposed in the Peace Treaty after World War II. The United Kingdom, on the other hand, has spent a relatively large part of its low aggregate investment on this item (1.2\% of GDP on average).

\subsection{Comparisons of the Broader Measure of Capital Formation}

The reason that the choice of types of investment to be included is important to international comparisons is that the composition of investment differs among countries. One of the reasons for the large gap between capital formation ratios in the United States and in the other 12 countries in conventional comparisons is that conventionally defined capital formation is a much smaller part of the broadly defined capital formation in the U.S. than in the other countries.

The changes in capital formation ratios in the United States and in the other 12 OECD countries generated by the adjustments of the ratios to include non-conventional forms of investment and to account for price differences across countries and over time are given in Table 10. 
Table 10

Change in the Ratio of Capital Formation to GDP

Generated by Each Adjustment

Per cent

U.S.

$\begin{array}{lllllll} & \begin{array}{l}\text { Consumer } \\ \text { Durables }\end{array} & \begin{array}{l}\text { Education } \\ \text { Expenditure }\end{array} & \text { R\&D } & \begin{array}{l}\text { Military } \\ \text { Capital }\end{array} & \begin{array}{l}\text { Constant } \\ \text { World Prices }\end{array} & \begin{array}{l}\text { All } \\ \text { Adj. }\end{array} \\ & & & & \text { Formation } \\ 1970-1974 & +4.4 & +7.1 & +2.1 & +1.5 & -0.2 & +13.4 \\ 1975-1979 & +4.4 & +6.7 & +2.0 & +1.0 & -0.8 & +11.6 \\ 1980-1984 & +3.6 & +6.2 & +2.2 & +1.4 & -0.9 & +10.7 \\ 1985-1989 & +4.6 & +6.0 & +2.4 & +1.7 & +0.5 & +14.4 \\ 1990-1994 & +4.2 & +6.6 & +2.4 & +1.3 & +3.1 & +18.8\end{array}$

12 Other Countries

$\begin{array}{lllllll} & \text { Consumer } & \text { Education } & \text { R\&D } & \text { Military } & \text { Constant } & \text { All } \\ & \text { Durables } & \text { Expenditure } & & \text { CF } & \text { World Prices } & \text { Adj. } \\ 1970-1974 & +4.0 & +5.1 & +1.3 & +0.5 & -2.3 & +7.6 \\ 1975-1979 & +4.5 & +5.6 & +1.3 & +0.5 & -1.8 & +9.1 \\ 1980-1984 & +4.1 & +5.5 & +1.5 & +0.6 & -1.2 & +9.3 \\ 1985-1989 & +4.4 & +5.4 & +1.7 & +0.6 & -0.7 & +10.9 \\ 1990-1994 & +3.8 & +5.5 & +1.8 & +0.5 & +0.4 & +13.0\end{array}$

Source: Appendix A, Tables

With a very few exceptions, every one of the unconventional forms of investment was more important in the United States in every period of our study. Furthermore, the unconventional forms of capital formation as a group were more important in the United States than in other countries in every period.

\footnotetext{
${ }^{10}$ The changes generated by the individual adjustments do not add up to the change generated by all adjustments because some of the adjustments to the measure of capital formation require a corresponding adjustment to the measure of GDP, while others do not. The All Adjustments column gives the change in the ratio of capital formation to GDP when the measure of capital formation is adjusted to incorporate price changes and all non-conventional forms of investment, and the measure of GDP is adjusted to
} 
Including the non-conventional types of capital formation in the comparison clearly brings the United States closer to the other countries.

Table 11 gives the comparison of investment shares including non-conventional forms of investment and taking account of price differences across countries.

Table 11

Share of Real Capital Formation in Real GDP

U.S. Relative to 12 Other Countries

Per cent

\begin{tabular}{llllll} 
& Including & Including & Including & Including & Including \\
& Only Consumer & Only Education & Only R\&D & Only Military & All Non-conv. \\
& Durables & Expenditure & Expenditure & Cap. Formation & Forms \\
$1970-1974$ & 86.8 & 92.6 & 86.4 & 86.8 & 98.9 \\
$1975-1979$ & 86.8 & 91.3 & 87.8 & 86.8 & 94.2 \\
$1980-1984$ & 91.4 & 95.8 & 95.4 & 95.8 & 100.0 \\
$1985-1989$ & 95.7 & 96.8 & 96.6 & 98.7 & 102.4 \\
$1990-1994$ & 101.6 & 102.2 & 100.5 & 102.6 & 107.4 \\
& \multicolumn{5}{r}{ Source: Appendix A, Tables } \\
\end{tabular}

By the broadly defined real capital formation measure, the ratio of capital formation to GDP in the United States was equal to that in the other 12 countries over the period since 1970 as a whole. In the last period the U.S. ratio was 7 per cent above average, as compared with the 17 per cent below average in the nominal, conventionally defined, figures of Table 1 .

The indications here are that broadly defined capital formation in the United States has not at any time since the early 1970 s been much below that of other developed countries relative to total output. Over the last ten years U.S. capital formation ratios have been above the average for the group. Even for believers in the role of capital formation rates as determinants of future growth, there is nothing in these data that suggests any tendency for the other countries to soon catch up to the U.S. in per capita output.

incorporate price changes, the estimated value of the services of consumer durables, and business enterprise R\&D expenditures. 


\subsection{Comparisons of Capital Formation per Capita and per Worker}

In most calculations of resource abundance, the United States is found to be a relatively capitalabundant country, with a high ratio of capital per worker and per individual in the population. The comparisons for both capital formation per worker and capital formation per capita; even in terms of conventionally defined capital, as given in Table 12, suggest that this high capital abundance will continue.

\section{Table 12}

Real Capital Formation, Conventionally Defined, per Capita and per Worker: U.S. as Per Cent of Average of 12 Other Countries

$\begin{array}{lll} & \text { Per Capita } & \text { Per W } \\ 1970-1974 & 118.7 & 125.4 \\ 1975-1979 & 117.6 & 118.1 \\ 1980-1984 & 121.3 & 119.7 \\ 1985-1989 & 121.0 & 116.6 \\ 1990-1994 & 124.3 & 117.7\end{array}$

Source: Appendix B, Table B-1

The United States has been investing more per person in the population and more per worker than the other countries for the whole quarter century in our data. In the early years, the margin was higher in investment per worker because the ratio of employment to population was lower in the United States, but with rising unemployment in Europe and rising labor force participation in the United States, the differential in the per capita ratio was higher at the end of the period.

The ratios for broadly defined capital formation (Table 13) show a considerably larger margin in favor of the United States. 
Table 13

Real Capital Formation, Broadly Defined, per Capita and per Worker:

U.S. as Per Cent of Average of 12 Other Countries

$\begin{array}{lll} & \text { Per Capita } & \text { Per Worker } \\ 1970-1974 & 149.7 & 157.6 \\ 1975-1979 & 137.3 & 137.5 \\ 1980-1984 & 135.4 & 132.9 \\ 1985-1989 & 139.6 & 133.8 \\ 1990-1994 & 144.6 & 136.6\end{array}$

Source: Appendix B, Table B-6

The use of the broader definition of capital formation enlarges the gap in favor of the United States, especially in the early 1970 s, when the other countries' non-conventional capital formation was particularly low. Since then, for two decades, the United States has been adding, in gross capital formation, about thirty per cent more than the average developed country to the capital provided for each worker and for each resident of the country. It would appear that U.S. industry will continue to be relatively capital intensive in the future.

\section{Conclusions}

Conventional measures of nominal capital formation give a misleading picture of the level of capital formation in the United States and other developed countries, changes in it over time, and the way U.S. capital formation compares with shares of capital formation in GDP in other developed countries. Measures of capital formation in real terms, taking account of price changes and price differences across countries for capital goods and other goods and services, paint a very different picture of the last quartercentury. That picture is even more different from the conventional one when a broader concept of capital formation is used, one that is at least as appropriate as the conventional one in national accounts and, we argue, is more consonant with the economic definition of capital formation.

Conventional measures show a ratio of capital formation to GDP in the United States fluctuating between 10 and 25 per cent below the average of the other countries, with the United States falling further behind the other countries since the beginning of the 1980s. In contrast, when we take account of the 
changes in prices of capital goods relative to other prices over time and differences in the prices of capital goods across countries, U.S. investment ratios in real terms are shown to have been increasing over time and moving toward the average of other developed countries, with the differential falling to less than 5 per cent in 1990-94.

When the concept of capital formation is broadened, as we argue it should be, to include household purchases of consumer durables, current expenditures on education, R\&D, and military capital formation, and account is also taken of international price differences, the United States is shown to have never been, since 1970, far below the other countries in the share of GDP devoted to capital formation. By 1990-94, the share of real broadly defined capital formation in real GDP in the United States was more than 5 per cent higher than the average in other developed countries.

Real capital formation per capita and per worker in the United States, even conventionally defined, were between 15 and 25 per cent higher than in the other developed countries over the period 1970-94. This margin in favor of the United States is considerably higher when we compare the adjusted broadly defined capital formation per capita and per worker. In terms of broadly defined capital, the United States has been investing between 30 and 60 per cent more per worker and per resident than other developed countries. This suggests that the United States will continue to be a relatively capital-abundant country in the future.

As we have pointed out, these are not the only definitions of capital formation that have some theoretical basis. The adjustments to the conventional measures suggested here were selected on the basis of reasonable feasibility without major research. The others that we consider of equal theoretical merit, on-the-job training costs and foregone earnings of students, were omitted solely for lack of data, but claims have been made also for some part of health care expenditures and child-rearing costs.

A next step would be to compare the usefulness of several versions of capital formation, varying in scope, for various purposes such as the explanation of economic growth. We hope to turn to this question next. 


\section{References}

Barro, Robert J. (1991), "Economic Growth in a Cross Section of Countries," Quarterly Journal of Economics, May 1991, no. 425, pp. 407-443.

Becker, G. S. (1964), Human Capital, Columbia University Press, New York.

Blades, Derek W., and Peter Sturm (1982), "The Concept and Measurement of Savings: The United States and Other Industrialized Countries," in Saving and Government Policy, Proceedings of a conference held at Melvin Village, New Hampshire, October 1982, sponsored by the Federal Reserve Bank of Boston.

Eisner, R (1989), The Total Incomes System of Accounts, University of Chicago Press, Chicago.

Eurostat (1988), Purchasing Power Parities and Gross Domestic Product in Real Terms, results 1985, Luxembourg: Office des Publications Officielles des Communautés Européennes.

Goldsmith, Raymond W. (1985), Comparative National Balance Sheets, Chicago, University of Chicago Press.

Friedman, Milton and Simon Kuznets (1945), Income from Independent Professional Practice, National Bureau of Economic Research, New York.

Hayashi, Fumio (1986), "Why is Japan's Saving Rate So Apparently High?" in Stanley Fischer, Ed., NBER Macroeconomics Annual, 1986, Cambridge, Mass. and London, MT Press for the National Bureau of Economic Research.

Horioka, Charles Yuji (1995), "Is Japan's Household Saving Rate Really High?" Institute of Social and Economic Research, Osaka University, and National Bureau of Economic Research.

Jorgenson, Dale W. and Barbara M. Fraumeni (1989), "The Accumulation of Human and Nonhuman Capital, 1948-1984," in Robert E. Lipsey and Helen Stone Tice, eds., The Measurement of Saving, Investment, and Wealth, Studies in Income and Wealth, vol.52, Chicago, University of Chicago Press for the NBER.

Katz, Arnold J. (1982), "The Value of Services Provided by the Stock of Consumer Durables, 1947-79: Alternative User Cost Estimates," in US Department of Commerce, Bureau of Economic Analysis, Measuring Nonmarket Economic Activity, BEA Working Papers, December 1982.

Kendrick, J. W. (1976), The Formation and Stocks of Total Capital, New York: National Bureau of Economic Research.

Kirova, Milka S. and Robert E. Lipsey (1997), Does the United States Invest "Too Little?", Federal Reserve Bank of St. Louis Working Paper No 97-020A.

Kravis, Irving B., Alan Heston and Robert Summers (1982), World Product and Income, International Comparisons of Real Gross Product, Baltimore, The Johns Hopkins University Press for the World Bank.

, and _ (1978), International Comparisons of Real Product and Purchasing Power, Baltimore, The Johns Hopkins University Press for the World Bank. 
Kravis, Irving B., Zoltan Kenessey, Alan Heston, and Robert Summers (1975), A System of International Comparisons of Gross Product and Purchasing Power, UN International Comparison Project, Phase I. Baltimore and London: Johns Hopkins University Press for the World Bank.

Kravis, Irving B., and Robert E. Lipsey (1991), "The International Comparison Program: Current Status and Problems," in Peter Hooper and J. David Richardson, eds., International Economic Transactions: Issues in Measurement and Empirical Research, Studies in Income and Wealth, Vol. 55, Chicago, University of Chicago Press.

Kuznets, Simon (1937), National Income and Capital Formation 1919-1935, New York, National Bureau of Economic Research.

Lipsey, Robert E., and Irving B. Kravis (1987), Saving and Economic Growth: Is the United States Really Falling Behind?, New York, The Conference Board, Inc..

Lipsey, Robert E., and Irving B. Kravis (1988), "Comparative National Saving and Investment: A Different View," presented at the Annual Meeting of the Western Economic Association, Los Angeles, July 1-3, 1988.

Mankiw, Gregory N., David Romer and David N. Weil (1992), "A Contribution to the Empirics of Economic Growth," Quarterly Journal of Economics, May 1992, no 429, pp. 407-437.

Marshall, Alfred (1890), Principles of Economics, London, Macmillan, 8th Edition, 1920.

Mincer, J. (1974), Schooling, Experience, and Earnings, Columbia University Press, New York. (1989), "Human Capital and the Labor Market: A Review of Current Research," Educational Researcher, 18, May 1989, pp. 27-34.

NATO $(1995,1996)$, NATO Review, March 1995 and January 1996.

Nonneman, Walter and Patrick Vanhoudt (1996), "A Further Augmentation of the Solow Model and the Empirics of Economic Growth for OECD Countries," Quarterly Journal of Economics, August 1996, no. 446 , pp. $943-953$.

OECD (1982), Science and Technology Indicators, Basic Statistical Series - Volume B, Gross National Expenditures on R\&D (GERD) 1963-1979.

(1983), Flows and Stocks of Fixed Capital, 1955-1980, Department of Economics and Statistics, Paris.

(1984), Science and Technology Indicators, Basic Statistical Series, Recent Results, Selected S\&T Indicators, 1979-1984.

(1985a), Purchasing Power Parities and Real Expenditures in the OECD, by Michael Ward, Paris.

(1985b), Education Statistics 1985-1992, Paris.

(1985c), Science and Technology Indicators, Basic Statistical Series, Volume B, Gross National Expenditures on R\&D, 1969-1982.

(1987), Purchasing Power Parities and Real Expenditures, 1985, Paris.

(1992), Purchasing Power Parities and Real Expenditures, EKS Results, Vol. 1, Paris. 
(1992, 1993, 1995, 1996), Education At a Glance: OECD Indicators, Paris.

(1995), Basic Science and Technology Statistics, 1981-1994, 5th edition, on diskette, Paris.

(1996), National Accounts, 1982-1994, Vol.I and Vol.II, electronic publication, Paris.

Penn World Table (Mark 5.6) (1994), http://www.nber.edu/pwt56.html.

Rebelo, Sergio (1991), "Long-Run Policy Analysis and Long-Run Growth," Journal of Political Economy, 1991, vol. 99 , no. 3, pp. 500-521.

Schultz, T. W. (1961), "Investment in Human Capital," American Economic Review 51, pp. 1-17.

Summers, Robert and Alan Heston (1991), "The Penn World Table (Mark 5): An Expanded Set of International Comparisons, 1950-1988," Quarterly Journal of Economics, May 1991, no. 425, pp. 327-368.

US Arms Control and Disarmament Agency (1995), Report on World Military Expenditures and Arms Transfers, http://www.acda.gov/reports.htm.

United Nations, Statistical Yearbook, various issues, New York, United Nations. 


\section{Appendix: Adjustments and Data ${ }^{11}$}

\section{Consumer Durables Adjustment}

Treating purchases of consumer goods as capital expenditures rather than as consumption requires estimates of the amount of these expenditures and of the value of the services of consumer durables, presumably equivalent to what would be charged for them if they were provided by the business sector. The consumer goods expenditures are added to the conventional capital formation, and the value of services provided by them is added to the conventional GDP.

Data on total durable goods expenditures for the period 1970-1994 are available from the OECD National Accounts, Vol. II, Table 2 for 10 of the countries we cover: Canada, Denmark, Finland, France, Japan, Netherlands, Norway, Sweden, the U.K., and the U.S.. For Belgium and Italy durable goods expenditures were approximated by the sum of expenditures on furniture, furnishings, household equipment, and personal transportation equipment, from the same source.

For Italy, although measures of total durables expenditures were reported, we approximated durables expenditures with the spending on furniture, furnishings, household equipment and personal transportation, because the reported total durables expenditures seemed unreasonably high. Both the implied share of durables expenditures in final houselold consumption expenditures and the level relative to the two subgroups were far out of line with those of other countries.

Durable goods expenditures for Germany were approximated using actual expenditures on personal transportation equipment and expenditures, estimated by us, on furniture, furnishings and household equipment. We estimated these expenditures using data for total expenditures on the broader group, furniture, furnishings, household equipment and operation, and an average share of the expenditures on the durable items, furniture, furnishings and household equipment in the total expenditures on the broader group. The average share was calculated using ICP data for 1970, 1975, 1985, 1990, 1993.

The value of services provided by durable goods is estimated on the basis of stocks of capital goods, as in an earlier BEA study. Data on the net current stock of consumer durables are available only for Canada and for the U.S. from the national balance sheets. For Japan data are available on the stock of the major consumer durables from the National Accounts of Japan. Following Horioka (1995) we used the average ratio of expenditures on all consumer durables to those on the major consumer durables to estimate the stock of all consumer durables in Japan. For all other countries we made a rough estimate of the stock of consumer durables in 1970, assuming that it equals four times the expenditures on durables during the year, an approximation that has been used before by Goldsmith (1985). Then we used the perpetual inventory method, assuming a $20 \%$ rate of depreciation, to estimate the net stock of consumer durables for the period 1971-1994. The value of services provided by consumer durables was estimated to

"Appendices A and B, containing the data and summary tables of results, are available in Kirova and Lipsey (1997) and on the Internet at http://www.stls.frb.org/research/reviewdat.html. 
equal $34 \%$ of the previous year's net stock of consumer durables ( $20 \%$ depreciation cost, $11 \%$ net return, $3 \%$ operating costs), following a methodology suggested by Katz (1982) in the BEA study.

\section{Educational Expenditures Adjustment}

The main source of data on education expenditures is the OECD National Accounts. In countries that provide complete data on both government and household consumption expenditures, the total of government and household expenditures on education was used. For countries in which government expenditures are not reported by the $O E C D$, data on current expenditures for public education, collected by UNESCO and published in the UN Statistical Yearbook were used instead. In some cases, depending on the availability of data, public or public and private expenditures reported in the OECD Education Statistics 1985-92 were used.

For Germany, which does not report household expenditures on education, data on education fees paid by households from the ICP for 1980, 1985, 1990, and 1993 were used to obtain ratios of private to public expenditures. We then used the average of these ratios to interpolate and extrapolate household education expenditures in Germany.

The OECD figures for household expenditures seem to match the figures given by "fees" in the ICP reports. It thus appears that the OECD data understate non-government education expenses by omitting that part paid for from sources other than fees.

\section{IIL. R\&D Expenditures Adjustment}

The adjustment for R\&D requires not only the addition of total $R \& D$ expenditures to capital formation, but the addition of business R\&D expenditures to GDP, since the standard accounts treat them as an expense of production rather than as a product. $R \& D$ performed by government and the non-profit sector are already in GDP, but as consumption rather than as capital formation.

Most of the R\&D data were taken from various issues of OECD Science and Technology Indicators, Basic Statistical Series and from the OECD Basic Science and Technology Statistics 19811994. Data for missing years were interpolated on a straight line.

\section{Military Spending Adjustment}

Data on total military expenditures were obtained from the U.S. Arms Control and Disarmament Agency, Report on World Military Expenditures and Arm Transfers. For NATO member countries we used the share of equipment and infrastructure expenditures, reported in the NATO Review, to calculate military capital expenditures. For the other OECD countries we used the average NATO member countries' share of equipment and infrastructure expenditures in total military expenditures to obtain an estimate of their military capital expenditures. 


\section{Cross-country comparison in international prices}

To account for the difference in the prices of investment goods relative to the prices of other goods and services across countries we converted the nominal measures of capital formation and GDP at national prices in national currency to real measures at international prices. The calculations are all in each year's current prices, with the U.S. purchasing power parities always set at 1.00 .

To make the conversion we use data on purchasing power parities (PPPs) for gross fixed capital formation and for GDP from the Penn World Table (Mark 5.6), which are provided until 1992. We extrapolated 1993 and 1994 PPPs for gross fixed capital formation and for GDP by data on price indices of GDP and of gross fixed capital formation reported in the OECD National Accounts, Vol. I.

The Penn World Table does not provide purchasing power parity estimates for a detailed breakdown of GDP. In order to make our calculations for the non-conventional elements in our broad measure of capital formation, we make use of price and quantity data from the OECD. These are a component of the ICP but there are some differences in the method. Some of these data have been published by Eurostat (1988) and OECD (1985a), (1987), and (1992), but we made use of more detailed data on diskettes provided by the OECD covering the years 1985, 1990, and 1993. The weighting systems and the index number formulas used by the Penn World Table and the OECD are different, but it was not possible for us to obtain exactly comparable measures.

For consumer durables, PPPs were available from the OECD data mentioned above and, for earlier years, from Kravis, Kenessey, Heston, and Summers (1975) and from Kravis, Heston, and Summers (1978) and (1982). Since it was clear from these earlier studies that PPPs for consumer durables were more strongly correlated with those for gross fixed capital formation than with those for consumption, we used the annual PPPs for gross fixed capital formation to convert the nominal measures of capital formation in consumer durables to real measures. For the conversion of the nominal measures of educational expenditures and expenditures on R\&D we used the PPPs for GDP as deflators. We deflated military capital formation expenditures using PPPs for gross fixed capital formation. 